\title{
Public Expenditure on Education and Economic Growth in the UK, 1833-2000 ${ }^{1}$
}

\author{
Vincent Carpentier \\ Institute of Education, University of London \\ E-mail: v.carpentier@ioe.ac.uk
}

This article is an attempt to show the value of a cross-disciplinary approach to historical studies of the relationship between education and economic growth. On the one hand empirical evidence about public expenditure on education in the nineteenth and twentieth centuries is provided. On the other, economic theory, with particular reference to the Kondratiev cycles, is employed in an attempt to relate such expenditure to economic performance. The primary aim of this article is to provide a better understanding of the past. Its secondary purpose is to supply data for an examination of current educational and economic policy.

\section{Introduction}

The relationship between education and economic performance is of considerable contemporary interest. We live in a 'knowledge economy' and education is widely, although by no means universally, regarded as investment, as a means of generating wealth and reducing unemployment. In the UK these connections have been expressed in institutional form, with the creation of the Department for Education and Employment (DfEE) by a Conservative government in 1995 and its replacement by a Department for Education and Skills (DfES) by a Labour administration in 2001. Historical perspectives upon this relationship have been supplied in a number of contexts. For example, in December 1997 the History of Education Society held a conference in Swansea on the

\footnotetext{
${ }^{1}$ I am most grateful to Professor Richard Aldrich for his assistance in preparing this article for publication. This research was supported through a European Commission Marie Curie Fellowship.
} 
theme of 'Education and Economic Performance'. Papers from this conference were published in a special edition of History of Education. ${ }^{2}$

This article presents the findings of recent research into educational expenditure in the UK during the last two centuries. ${ }^{3}$ This is a largely unexplored field. ${ }^{4}$ The findings are of considerable interest in their own right and also important for their potential contribution to historical debates about the relationship between education and economic performance. The research originated as part of a substantial series of investigations into historical relationships between education and economic performance undertaken from the University of Montpellier. ${ }^{5}$ Studies of these relationships with respect to France, Germany and Spain have already been published and overall hypotheses advanced. ${ }^{6}$ These have principally been located within the 'long wave' or 'long cycle' interpretations

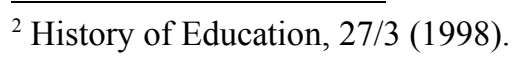

${ }^{3}$ V. Carpentier, Développement éducatif et performances économiques au Royaume-Uni: 19ème et 20ème siècles, Thèse de Doctorat en Sciences Economiques, Université Montpellier I, 2000; V. Carpentier, Système éducatif et performances économiques au Royaume-Uni: 19ème et 20ème siècles (Paris: L’Harmattan, 2001); V. Carpentier, 'Effort public d'éducation et croissance économique de long terme au Royaume-Uni', Economies et Sociétés, Série AF, Histoire Economique Quantitative. 28 (2001).

${ }^{4}$ But see, for example, J. Vaizey, The Costs of Education (London: George Allen and Unwin, 1958), 17; F. Edding and D. Berstecher, International Developments of Educational Expenditures 1950-1965 (Paris: Statistical Reports \& Studies, UNESCO, 1969); A. Peacock, H. Glennerster and R. Lavers, Educational Finance, its Sources and Uses in the United Kingdom (Edimburgh and London: Oliver \& Boyd, 1968); N. Morris, 'Public Expenditure on Education in the 1860s', Oxford Review of Education. 3 (1977), 3-19.

5 The 'Analyse des Transformations Economiques et Histoire Quantitative' group is a part of the LAMETA, a research unit attached to National Center of Scientific Research (CNRS) located in the Economic Department of the University Montpellier 1.

${ }^{6}$ L. Fontvieille, 'Education, Growth and Long Cycles: The Case of France in the 19th and 20th Centuries' in G. Tortella (Ed.) Education and Economic development since the Industrial Revolution, (Valencia: Generalitat valenciana, 1990) ; A. Carry, 'Le compte satellite rétrospectif de l'éducation en France: 18201996', Economies et Sociétés, Série AF, Histoire quantitative de l'économie française. 25, (1999); C. Diebolt, L'évolution de longue période du système éducatif Allemand XIXème et XXème siècles, Economies et Sociétés, Cahiers de l'I.S.M.E.A., n²-3 P.U.G.. (1997); C. Diebolt, Dépenses d'éducation et cycles économiques en Espagne aux $19^{\text {ime }}$ et $20^{\text {ime }}$ siècles (Paris: Logiques Economiques, L'Harmattan, 2000); A. Bouslimani, systèmes éducatifs et trajectoires de développement dans les pays du Maghreb, Thèse de Doctorat en Sciences Economiques, Université Montpellier I, forthcoming. 
of economists and historians, with particular reference to the Kondratiev cycles. ${ }^{7}$ Comparable interpretations within a British context need to take further account of an historiography of economic performance, whether related to education or other factors, that has often been located within frameworks of decline. ${ }^{8}$

There is considerable potential for historians of education in the UK to make an input into current debates about the relationships between education and economic growth. ${ }^{9}$ There are two requisites. The first is an understanding of economic history and economic theory. The second is a reliable set of statistics.

This article is divided in four sections. It begins with a review of the methodological and statistical problems involved in the collection and treatment of the data and then moves to a presentation of the major findings. These are expressed in a series of graphs of educational expenditure across the nineteenth and twentieth centuries. The relationships between such educational expenditures and the performance of the British economy are next considered. Finally, some overall conclusions are drawn.

\section{Definition and measurement of public expenditure on education}

One of the key issues in debates about educational development in the UK is the availability and reliability of statistics. According to John Vaizey:

The perennial financial difficulties of education committees are so familiar that they need no reiteration. And yet nowhere is there to be found an adequate exposition of how much has been spent on what and why. In part,

\footnotetext{
${ }^{7}$ There is a vast literature upon this topic. For a recent overview see F. Loucã and J. Reijnders (Eds) The Foundations of Long Wave Theory (Cheltenham: Edward Elgar Publishing, 1999); N. D. Kondratieff (1924) 'Sur les concepts de statique, de dynamique, et de conjoncture en économie ", 1-46, in L. Fontvieille (Ed.), Les grands cycles de la conjoncture (Paris: Economica, 1992).

${ }^{8}$ This is also a much covered and contested issue. For a recent overview with specific reference to the period 1870-1914 see J.-P. Dormois and M. Dintenfass (Eds) The British Industrial Decline (London: Routledge, 1999).

${ }^{9}$ For two recent examples see R. Aldrich, Education for the Nation (London: Cassell, 1996), chapter six and R. Aldrich, D. Crook and D. Watson, Education and Employment: The DfEE and its Place in History (London: Institute of Education, 2000).
} 
this deficiency - and it must be admitted that it is a grave one - is to be ascribed to inadequate intellectual tools. ${ }^{10}$

Nevertheless, as Hough points out, in the mid-1960s, partially in response to Vaizey's criticisms, progress was made by the creation of government statistical reviews of education. ${ }^{11}$ During the 1980 s, further data were provided about public educational expenditure and enrolment. ${ }^{12}$ Nevertheless, detailed studies are only available for the short-term; current longer-term studies are not comprehensive. ${ }^{13}$ A long-term statistical description of the UK educational system with specific reference to public expenditure has remained elusive.

Prior to the industrial revolution, education in the UK was composed of heterogeneous and hermetic subsystems. There were few similarities between charity schools provided for the children of the poor and public schools attended by the sons of the wealthy. Industrialisation did not destroy this system but transformed it in part. For example, charity schools were replaced by Sunday schools while public schools for boys continued.

The major transformation of the education system occurred as a result of the injection of public expenditure. Central government grants were initially made to voluntary schools, particularly those of the National and British societies. These were later complemented by grants to the schools run by local authorities and to universities and university colleges. The 1830s signalled not only the beginnings of a public and professional educational system but also the arrival of reliable data on public educational expenditure. ${ }^{14}$ On the other hand, despite the work of Vaizey and Bamford, reliable data

${ }^{10} \mathrm{~J}$. Vaizey, The Costs of Education, 17.

${ }^{11}$ J. R. Hough, Education and the National Economy (London: Croom Helm, 1987), 155.

${ }^{12}$ P. Flora, State, Economy and Society in Western Europe 1815-1975, Vol.1 (Frankfurt: Camps Verlag, $1983)$; B.R. Mitchell, British Historical Statistics (Cambridge: Cambridge University Press, 1988).

${ }^{13}$ V. Carpentier, 'The link between Educational Development and Economic Performances in the United Kingdom since the Industrial Revolution'. Paper presented to Annual History of Education Conference, Swansea, 12-14 December 1997.

${ }^{14}$ T. W. Laqueur, 'Working Class Demand and the Growth of English Elementary Education, 1750-1850', 193-203, in L. Stone (Ed) Schooling and Society, Studies in the History of Education (London: The Johns 
about private systems of education were notoriously difficult to collect before the Independent Schools Information Service supplied comprehensive statistics. ${ }^{15}$

Public educational effort provides a homogeneous and coherent framework within which to investigate links between education and economic growth. The maintained system currently accounts for more than $90 \%$ of educational expenditure and enrolment. Although for much of the period covered by this article the UK educational system was semi-public rather than public when compared with those of other countries, a very substantial range of sources has been consulted and care taken to avoid double counting. ${ }^{16}$ Hopkins University Press, 1976).

15 J. Vaizey, The Costs of Education; T. W. Bamford, Public School Data. A Compilation of Data on Public and Related Schools from 1866 (Institute of Education, University of Hull, 1974); Independent Schools Information Service Annual Census, Statistical Survey of Independent Schools (London: I.S.I.S., 1980-2000).

16 Board of Education, (1902-1922) Statistics of Public Education, His Majesty's Stationery Office (H.M.S.O.), London; Central Statistical Office (Various Years) Annual Abstract of Statistics, H.M.S.O., London; Central Statistical Office (Various Years) Statistical Abstract for the United Kingdom, H.M.S.O., London; Central Statistical Office (1938-1968) Annual Abstract of Statistics, H.M.S.O., London; Central Statistical Office (1849-1938) Statistical Abstract for the United Kingdom, H.M.S.O., London; Government of Northern Ireland (1965) Public Education in Northern Ireland, H.M.S.O., Belfast; Government Statistical Service (1967-1998) Education Statistics for the United Kingdom, H.M.S.O., London; Government Statistical Service (1999-2000) Education and Training Statistics for the United Kindom, H.M.S.O., London Government Statistical Service (1990-1995) Higher Education Statistics for the United Kingdom, H.M.S.O., London; Ministry of Education (1961-1995) Statistics of Education, H.M.S.O., London; Ministry of Education, (1965-1995) Statistics in Education in Wales, H.M.S.O., Cardiff; Northern Ireland Ministry of Education, (1970-1988) Education Statistics in Northern Ireland, H.M.S.O., Belfast; Parliamentary Papers (Various Years) Civil Services Accounts - Education, science and art, H.M.S.O., London; Parliamentary Papers (Various Years) Report From Commissioners, Statistic of Inspection of Annual Grant Schools in England and Wales; Parliamentary Papers (Various Years) Report From Commissionners, The State of Popular Education in England; Parliamentary Papers (1886) Report From Commissionners, $\mathrm{n}^{\circ} 13$, Returns furnished by Mr Cumin relating to Schools in England and Wales, Vol. LXV; Parliamentary Papers (1898) Report From Commissioners, Education (England and Wales), Special Reports, vol. XXIV; Parliamentary Papers (Various Years) Accounts and Papers, Statistics of Inspection of Annual Grant Schools in England \& Wales; Parliamentary Papers (1875-1902) Accounts and Papers, Statistics of Inspection of Annual Grant Schools in Scotland; Parliamentary Papers (Various Years 1 Accounts and Papers, Civil Appropriation Accounts; Parliamentary Papers (Various Years) 
The methodology is that of quantitative history, which can be defined as a retrospective history ruled by principles of national accounting. This implies an exhaustive and coherent system of collection and processing which provides homogenous and comparable data. ${ }^{17}$

Public educational expenditure, as represented in the following figures, includes preschool and compulsory education (nursery, primary, secondary, special education), post compulsory education (further education, higher education and teacher training treated separately) and related expenditures from administration to school welfare (e.g. transport, meals and milk, medicine, sport). Private schools subsidised or aided by central or local authorities are also included. Figures include all Ireland until 1922 and only Northern Ireland thereafter. A full explanation of the methodology employed and a complete set of statistics are to be found in Carpentier (2001). ${ }^{18}$

\section{The long-term growth of public expenditure on education}

The first figure demonstrates the massive rise of public expenditure on education from 1833 to 1999 . Over this period the average annual growth rate stood at $8.1 \%$ at current prices and $5.7 \%$ at constant 1990 prices. One explanation for such growth is that the increased wealth of the country enabled more money to be devoted to education. Figure 2 , however, shows that such growth was also fuelled by a rise in the percentage of public resources devoted to education as a share of GDP. In 1833, public expenditure on education amounted to only $0.01 \%$ of GDP; in 1999 , it constituted $4.31 \%$.

\footnotetext{
Memorandum on the Board of Education Estimates, H.M.S.O.; Scottish Educational Department (19801988) Scottish Education Statistics, H.M.S.O., Edinburgh; Scottish Office (Various Years) Scottish Abstract of Statistics, Government Statistical Service, Edinburgh; University Grants Committee (19191995) Returns from Universities and University Colleges in Receipt of the Treasury Grants, H.M.S.O.; University Grants Committee (1980-1995) University Statistics, Vol. 3, Finance, Universities' Statistical Records.

${ }^{17}$ J. Marczewski, ' Histoire quantitative, buts et méthodes ', Cahiers de l'Institut de sciences économiques appliquées Série A.F.. 15 (1961), 3-54.

${ }^{18} \mathrm{~V}$. Carpentier, Système éducatif et performances économiques au Royaume-Uni: 19ème et 20ème siècles (Paris: L’Harmattan, 2001).
} 
Figure 1 - Public Expenditure on Education at Current and 1990 prices, UK, 1833-1999 (log.). $\mathrm{R}^{2}=0.985$

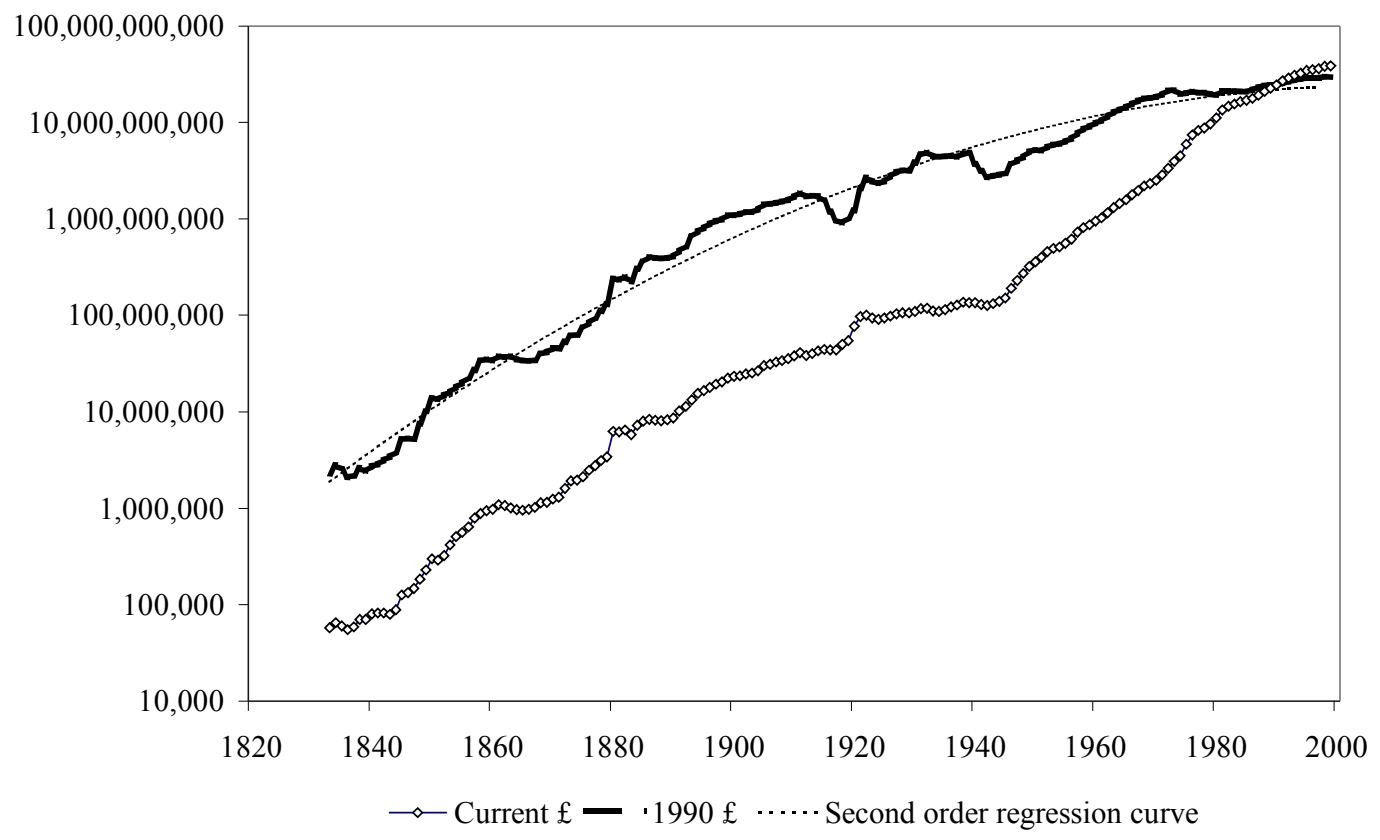

Figure 2 - Public Expenditure on Education as a Share of GDP, UK, 1833-1999. R²=0.97

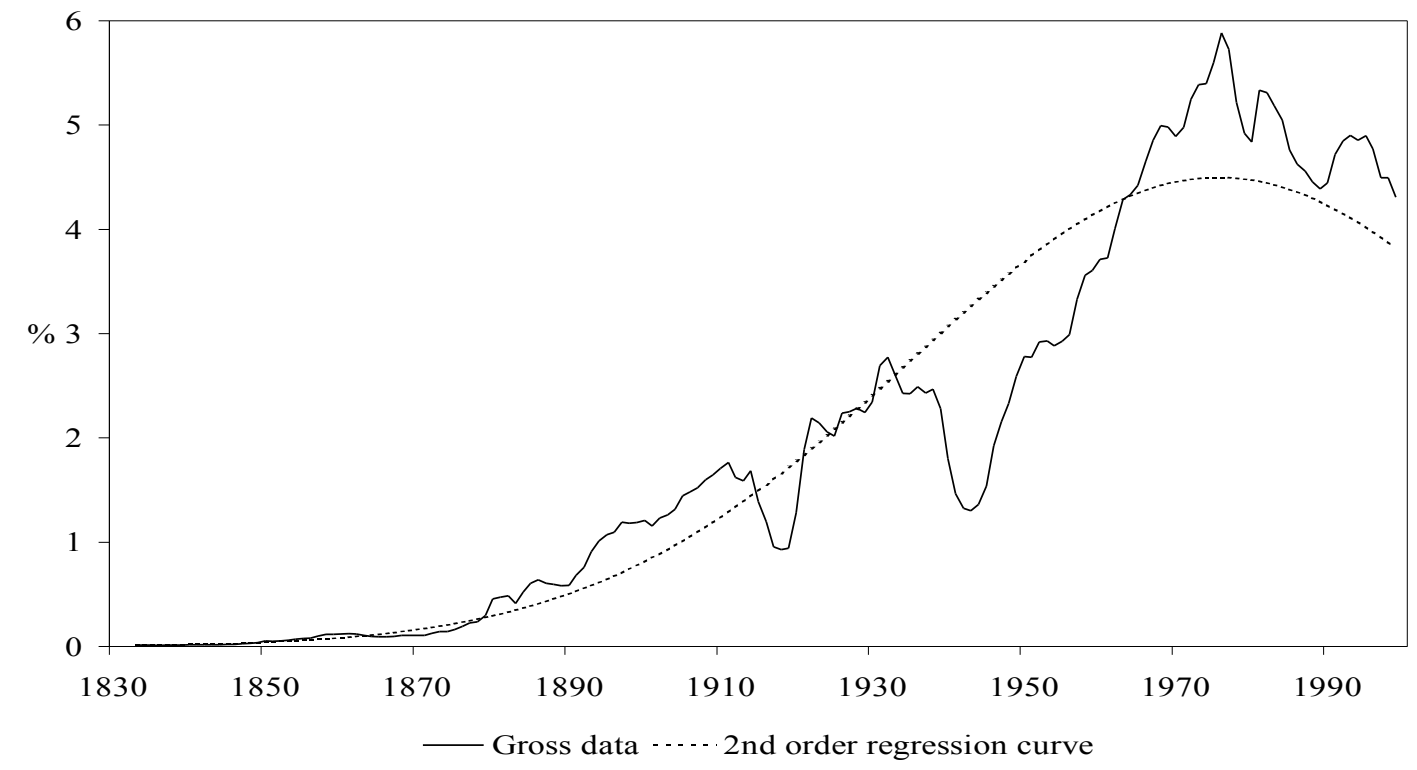


Figure 3- Public expenditure per pupil at 1990 prices, UK, 1854-1997

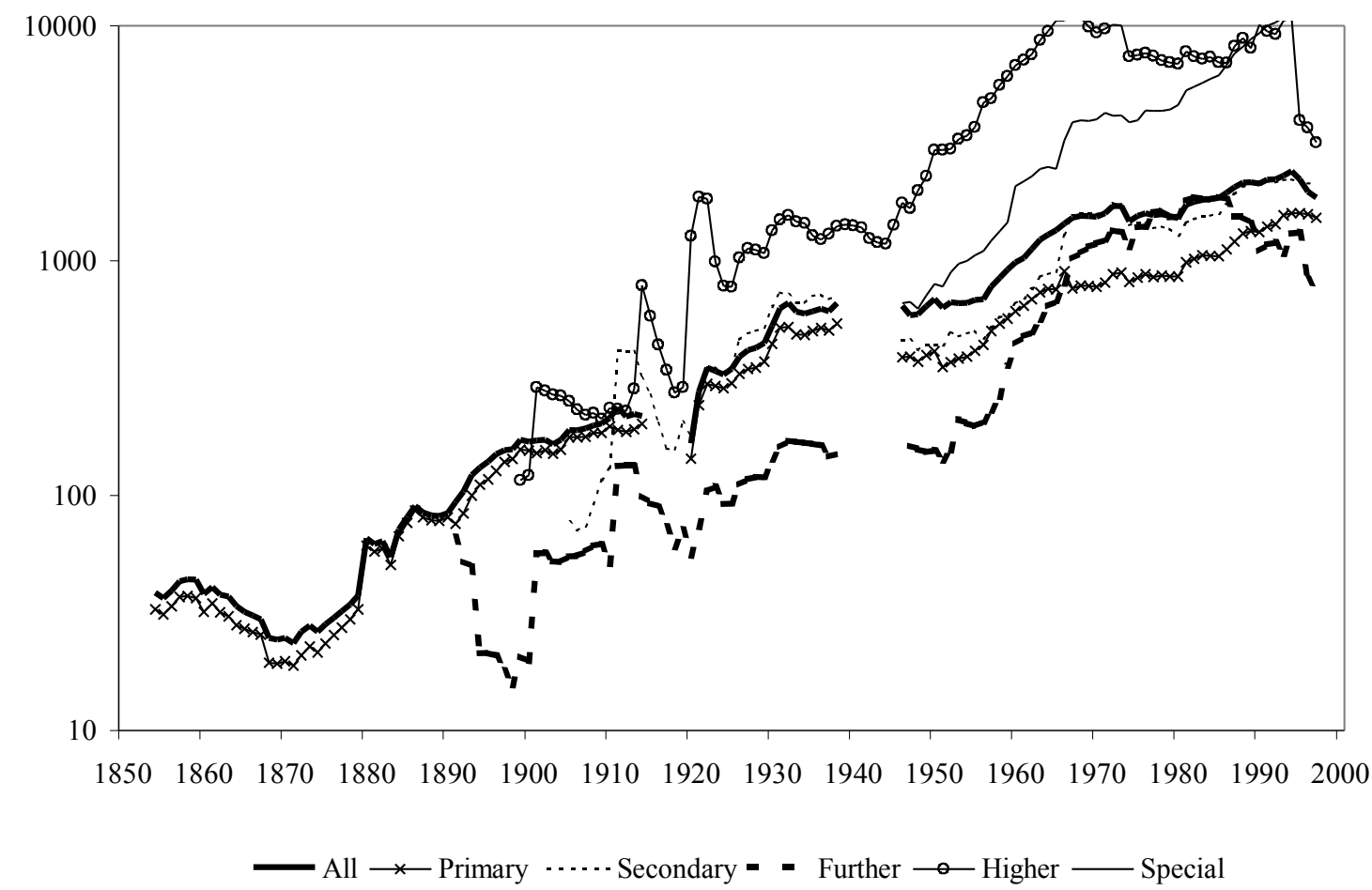

Thus education expenditure participated fully in the long-term growth of all public expenditure in the UK observed by A. T. Peacock and J. Wiseman. ${ }^{19}$ Indeed, in 1999 public expenditure on education represented $11.5 \%$ of all public expenditure compared to $6.6 \%$ in 1890 .

One of the obvious reasons for increased public expenditure on education is to be found in the growth in numbers of pupils and students. Enrolment in the semi-public system grew from less than 500000 in 1854 to more than 14 millions in 1996. This represented a rise from $5 \%$ to $85 \%$ of the 5-to-24 years old age group. Such growth, however, is not a sufficient explanation by itself. As figure 3 shows, expenditure per pupil at 1990 prices was some 30 times greater than in the $1850 \mathrm{~s}$.

${ }^{19}$ A. T. Peacock and J. Wiseman, The Growth of Public Expenditure in the United Kingdom (London: Oxford University Press, 1994). 
Figures 1-3 demonstrate that the rise in public expenditure on education in the UK during the nineteenth and twentieth centuries was a complex event. Fritz Ringer has drawn attention to the dangers of considering educational growth simply in economic terms, ${ }^{20}$ and it is clear that education influences, and is influenced by, a wide range of economic, social, political and cultural factors.

\section{The non-linear growth of public effort and the transformation of UK educational system towards a knowledge economy}

Figure 4 shows that in spite of the overall growth of educational expenditure in the UK in the nineteenth and twentieth centuries there were also significant fluctuations.

Figure 4- Public Expenditure on Education at 1990 prices, UK, 1833-1997 (Second Order Deviation from the Regression Curve and 9- Year Moving Averages) ${ }^{21}$

\footnotetext{
${ }^{20}$ F. Ringer, 'Introduction', 1-12, in D. K. Muller, F. Ringer and B. Simon The Rise of the Modern Educational System: Structural Change and Social Reproduction 1870-1920 (Cambridge: Cambridge University Press, 1987), 1.

${ }^{21}$ A regression curve is the best fitting curve drawn through a scatter-plot of two variables. It is chosen to come as close to the points as possible. A regression curve represents then the shape of the relationship between the variables (here the expenditure and the time) and the long-term trend if the series were regularly distributed. The deviations from the regression curve represent the cyclical fluctuations around the trend. Nine Year Moving Averages are sliding averages that smooth the data in order to ease the examination of the trend and changes. For more details, see P. Hudson, History by Numbers: An Introduction to Quantitative Approaches (London: Arnold, 2000).
} 


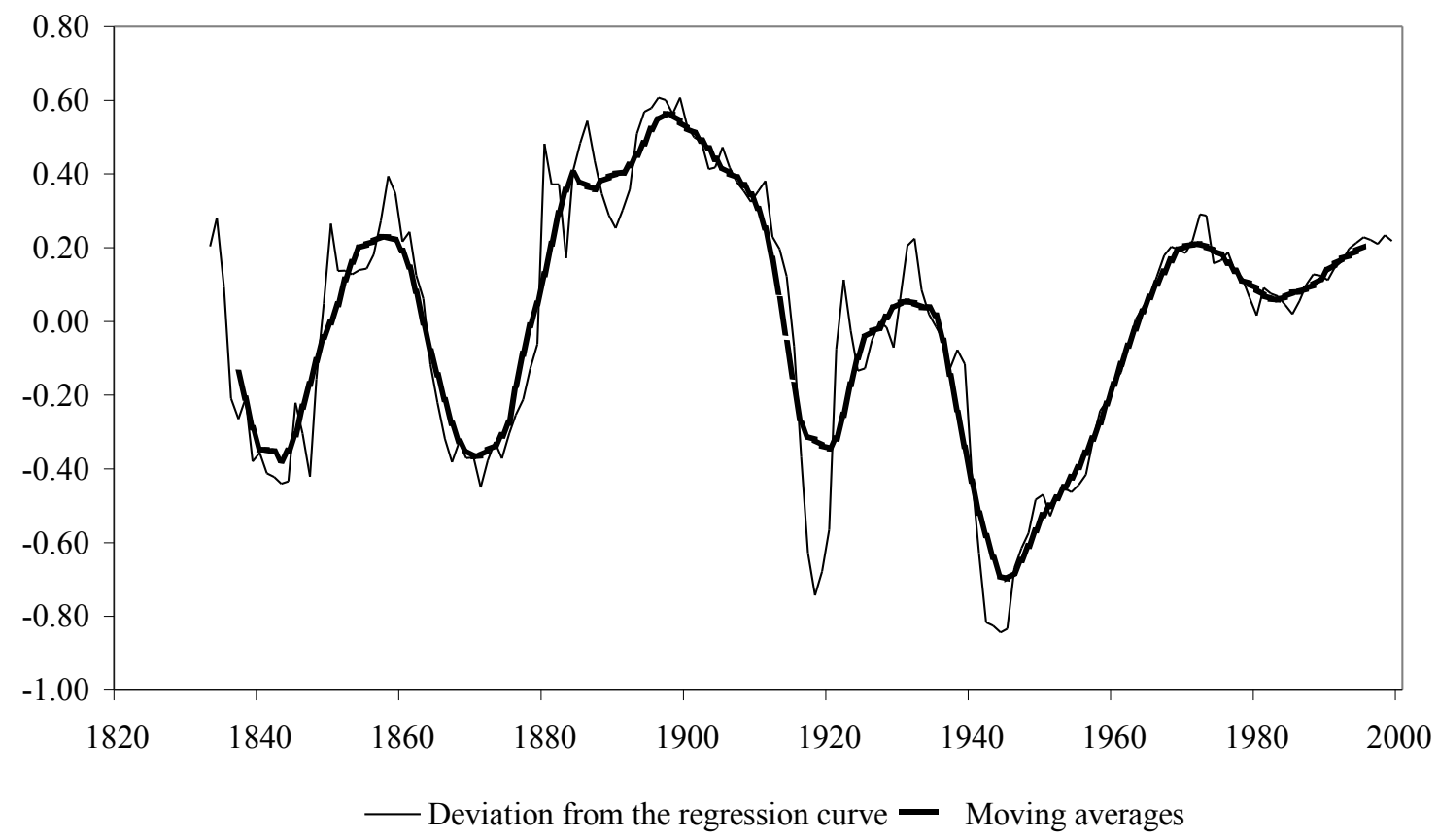

One of the main purposes of the research undertaken at Montpellier has been to compare such fluctuations in public expenditure on education with fluctuations in the economy, with particular reference to the Kondratiev cycles. ${ }^{22}$

Figure 5- Gross Domestic Product (1938 prices) UK, 1833-1999 (second order deviation from the regression curve and 9- year moving averages) ${ }^{23}$

\footnotetext{
${ }^{22}$ The duration of Kondratiev cycles differs according to authors and to countries. In general, four long waves of approximately 50 years have been identified, each of them showing expansion and depression phases: (1790-1820/1820-1848); (1848-1870/1870-1897); (1897-1913/1913-1945); (1945-1973/1973-?). See E. Mandel, Long Waves of Capitalist Development (London: Verso, 1995), 3. See also J. S. Goldstein, Long Cycles, Prosperity and War in the Modern Age (London: Yale University Press, 1988), 64. N. D. Kondratieff, 1924,

${ }^{23}$ B. R. Mitchell, British Historical Statistics (Cambridge: Cambridge University Press, 1988), 837; Central Statistical Office (1968-2000) Annual Abstract of Statistics, H.M.S., London.
} 


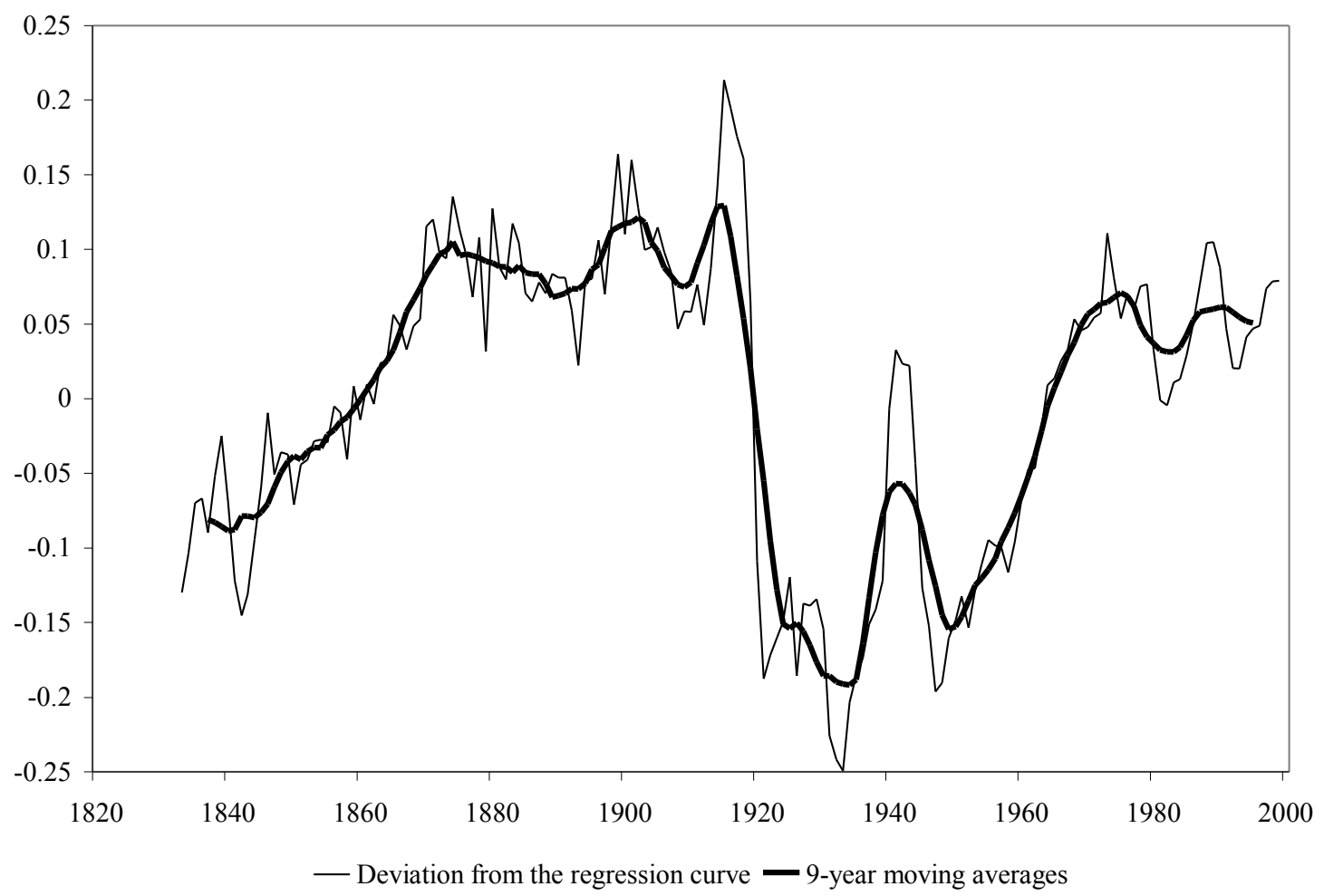

While Kondratiev cycles remain highly contentious, ${ }^{24}$ they nevertheless provide a useful means of exploring economic changes over the last two centuries. ${ }^{25}$ They may also indicate changes in the role of education in terms of investment and consumption. Thus as figures 4 and 5 indicate, prior to 1945, in relative terms educational expenditure seems to have increased during periods of economic downturn and decreased when the economy was strong. After 1945, however, the situation was reversed. Educational expenditure grew during the period of relative prosperity following the end of the Second World War, but began to decline in relative terms following the economic downturn triggered by the

${ }^{24}$ W. A. Lewis, Growth and Fluctuations, 1870-1913 (London: Allen \& Unwin, 1978); S. Solomou, Phases of Economic Growth, 1850-1973, Kondratieff Waves and Kuznets Swings (Cambridge: Cambridge University Press, 1987); J. L. Escudier, 'Long-Term Movement of the Economy: Terminology and Theoretical Options', 3-24, in F. Loucã and J. Reijnders (Eds) The Foundations of Long Wave Theory, vol. 1 (Cheltenham: Edward Elgar Publishing, 1999).

${ }^{25}$ For a recent survey and interpretation see C. Freeman and F. Louçâ, As Time Goes By. From the Industrial Revolutions to the Information Revolution (Oxford: Oxford University Press, 2001). 
oil crisis of 1973. Both public expenditure on education as a percentage of GDP and expenditure per pupil also exhibited a countercyclical fluctuation with respect to general economic growth before 1945 and a procyclical relationship thereafter. In the light of this evidence it can be argued that the end of the Second World War marked a major transformation in the relationship between public expenditure on education and economic growth.

The theory of systemic regulation provides one means of explaining this process. ${ }^{26}$ Education engages human beings both as individuals and citizens and also as producers. ${ }^{27}$ The economic process can be defined as the result of the dialectical links occurring during the mobilisation of human and material productive forces. Thus human and economic development may be in opposition, as before 1945, or in conjunction thereafter. Louis Fontvieille considered these complementary and contradictory links between capital and the labour force to be the origin of long waves, as they express the structural transformations of the economy. ${ }^{28}$ Thus Kondratiev cycles represent a regulation process based on the alternation of phases of operation and development, which respectively describe the deepening and the reduction of imbalances between productive forces. Educational expenditure is a central element in correcting these imbalances and thus educational development itself may be traced in long waves.

The regulation of upward economic phases is based on productivity resting on the relative saving of labour. This operating mode driven by high profits is efficient during the first part of the boom but progressively drives the economic system to the overaccumulation of capital, which results from the excess of investment combined with and aggravated by the underdevelopment of the labour force. The weaker growth of the educational effort, imposed by the conditions of valorisation of capital, is thus one of the

\footnotetext{
${ }^{26}$ P. Boccara, Etudes sur le capitalisme monopoliste d'Etat, sa crise et son issue (Paris: Editions sociales, 1974).

${ }^{27}$ Fontvieille, Education, Growth and Long Cycles.

${ }^{28}$ L. Fontvieille, 'Les mouvements longs de Kondratieff et la théorie de la régulation', Issues. 4 (1979), 3-

36; L. Fontvieille 'Long Cycle Theory: Dialectical and Historical Analysis', 314-342, in F. Loucã and J. Reijnders (Eds) The Foundations of Long Wave Theory, vol. 1 (Cheltenham: Edward Elgar Publishing, 1999).
} 
elements leading to the neglect of technical progress and of the development of the labour force and finally exhausts long-term economic growth perspectives.

The downward phase is then characterised by a fall in the rate of profit leading to an endogenous search for qualitative structural transformations of the economic system to enhance its efficiency. Productivity is then enhanced by an intensive growth of capital combined with a rise of spending on labour to reduce imbalances. ${ }^{29}$ Public educational effort participates in the restoration of the upward phases. By limiting the mass of capital to be valorised while generating new productivity gains by its effects on the qualitative development of the labour force in conjunction with technical progress, education expenditure produces a new cycle of accumulation generating economic growth. ${ }^{30}$

Thus, before 1945, the rapid growth of public expenditure on education during periods of economic downturn may be explained in terms of an attempt to revive the economy. The procyclical approach to educational expenditure post 1945 may represent the recognition of education as a driving force in the economic system rather than simply a means of correction. These hypotheses are explored in detail in the next two sections.

\section{Pre 1945 - public expenditure on education as a response to economic crisis}

During the classic period of the first industrial revolution, 1790-1820, investment in machinery and plant took precedence over expenditure on education. The need for more formal scientific and technological education was not acknowledged. ${ }^{31}$ No public grants were made and no formal system of education was launched. Self-taught and pragmatic pioneers were to the fore; charity and Sunday schools provided a modicum of education

\footnotetext{
${ }^{29} \mathrm{~V}$. De Faria showed that there is a relationship between changes in scale of wages and educational fluctuations in connection with long waves. V. De Faria, 'L'évolution de long terme de la hiérarchie des rémunérations', Economies et Sociétés, Série AF, Histoire quantitative de l'économie française. 27 (2000).

30 The systemic regulation confirms the effect of innovation on economic growth shown by the neoschumpeterians; see M. F. Conus 'L'héritage de la pensée économique de Schumpeter sur les mouvements économiques de longue période : avancées ou recul des néo-schumpéteriens', 147-170, in Les cahiers de l'association Charles Gide pour l'étude de la pensée économique, Les mouvements longs dans la pensée économique, 5 (1993); C. Freeman and F. Louçâ, As Time Goes By. From the Industrial Revolutions to the Information Revolution (Oxford: Oxford University Press, 2001).
}

${ }^{31}$ A. Tylecote, The Long Wave in the World Economy (London: Routledge, 1993), 63. 
with a strong emphasis on social control. The period 1830-1850, however, which saw a slowdown in the dynamic of the first industrial revolution also witnessed a series of public initiatives in education. The Factory Act of 1833 imposed a limit on the hours of work of some children and a requirement for some schooling. ${ }^{32}$ Over the next 20 years, as figure 1 shows, public expenditure on education grew some six fold. A Committee of the Privy Council was set up to oversee public intervention in education and inspectors appointed. Public grants were given to voluntary schools to supplement charitable donations and parental contributions. In the 1840s the range of grants was extended to include the training of teachers.

The 1850-1870 Victorian golden age was characterised by a more stringent approach to educational expenditure, exemplified by the Revised Code of 1862. (see figure 4). As Norman Morris has shown, however, this approach was not confined simply to payment by results. ${ }^{33}$ Figure 6 demonstrates that during this period the relative contribution made by donations declined while that of fees increased. Michael Sanderson has suggested that as prospects for investment increased, donations to schools declined. ${ }^{34}$ Enrolment and teacher pupil ratios were both adversely affected. The decline in fees was only partially compensated for by growth in public funding.

Figure 6- Income Structure of state-aided schools, England and Wales, 1851-1902

\footnotetext{
${ }^{32}$ C. Nardinelli, 'Child Labor and the Factory Acts', The Journal of Economic History. XL (1980), 730746; M. Blaug, 'The Productivity of Capital in the Lancashire Cotton Industry during the Nineteenth Century', The Economic History Review. XIII (1961), 368.

${ }^{33}$ N. Morris, 'Public Expenditure on Education in the 1860's', Oxford Review of Education. 3 (1977), 3-19.

${ }^{34}$ M. Sanderson, Education, Economic Changes and Society in England 1780-1870 (London: Macmillan, 1991).
} 


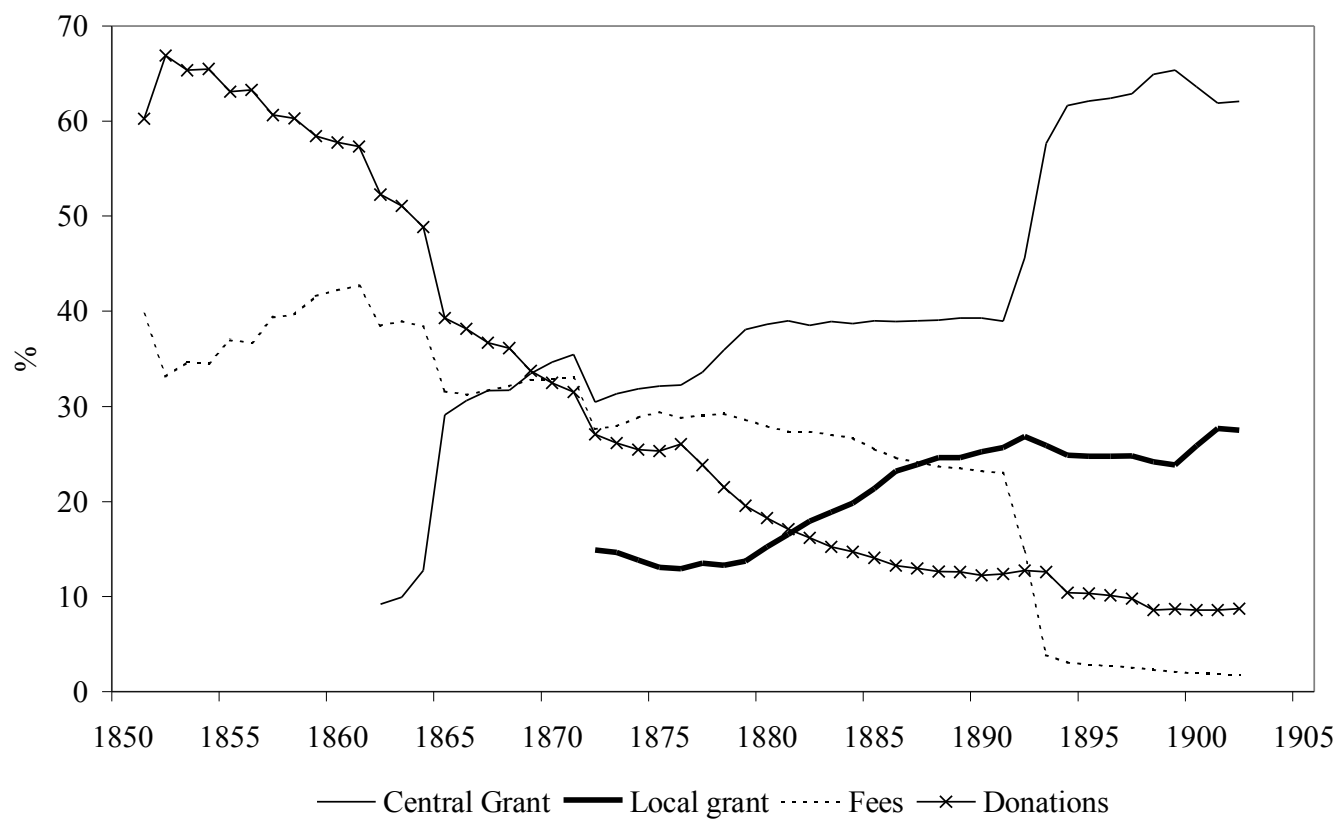

In 1870, in introducing the Education Bill to Parliament, W.E. Forster, made a direct link between educational investment and economic growth when he declared that 'Upon the speedy provision of elementary education depends our industrial prosperity' ${ }^{35}$ Designed to fill up the gaps in the provision of elementary schooling, the Forster Act and the creation of school boards heralded a significant transformation in the role of the state in education. In 1868 the public contribution to the income of state-aided schools was 33\%, rising to $60 \%$ in 1887 and $90 \%$ in 1902 (figure 6). The new board schools were financed by central grants and local rates. In 1891 fees were abolished in elementary schools.

Between 1870 and 1897 there was a 20 fold increase in public expenditure on education, which represented a rise from $0.1 \%$ to $1.2 \%$ of GDP. Pupil enrolment increased threefold and many substantial new schools were built. The teacher-pupil ratio improved and less reliance was placed upon pupil teachers. This massive investment in education occurred at a time of economic downturn, the Great Depression.

${ }^{35}$ R. Williams, The Long Revolution (London: Chatto \& Windus, 1961), 141. 
There is some debate among economic historians as to whether the years 1897-1914 should be seen as a continuation of the Great Depression or as a period of economic revival. As figure 5 indicates, the early years of the twentieth century did witness some economic recovery; they were also characterised by major structural changes in education.

The Education Act of 1902 saw the replacement of school boards by Local Education Authorities (LEAs). Although LEAs were given a much wider remit - to provide elementary education and 'take such steps as seem to them desirable, to supply or aid the supply of education other than elementary' - this measure may also be seen as a means of curbing the perceived extravagance of some of the larger school boards. There was an increase in the percentage of total educational expenditure financed from local rates, from $43 \%$ in 1899 to $56 \%$ in $1913 .{ }^{36}$ Nevertheless, overall education expenditure with reference to GDP rose only from $1.2 \%$ in 1897 to $1.6 \%$ in 1913.

Between 1902 and 1913, enrolment in public secondary schools rose from 60000 to 230 000 children and this sector's share of the total public education budget increased from $1 \%$ to $5 \%$. Enrolment in technical colleges increased from 500000 in 1895 to nearly a million in 1914. Technical education, however, was not a priority. ${ }^{37}{ }^{38}$ Only 5\% of students were engaged in full-time courses. The majority were engaged in part-time $(15 \%)$ or evening $(80 \%)$ studies. Other types of spending were envisaged. The 1906 Education Provisions of Meals Act established meals for pupils at cost price. ${ }^{39}$ The 1907 Education Administrative Provisions Act provided for medical inspections in elementary schools. Nevertheless, it appears that this period was characterised by an inadequate financial commitment to the ambitious transformations that were planned.

\footnotetext{
${ }^{36} \mathrm{~V}$. Carpentier, Développement éducatif et performances économiques au Royaume-Uni: 19ème et 20ème siècles, Thèse de Doctorat en Sciences Economiques, Université Montpellier I, 2000265.

${ }^{37}$ A. Guagnini, 'The Training of Mechanical Engineers in England, 1850-1914', 16-41, in R. Fox and A. Guagnini (Eds) Education, Technology and Industrial Performance in Europe, 1850-1939, (Cambridge: Cambridge University Press, 1993), 37.

${ }^{38}$ A. Green and N. Lucas, FE and Lifelong Learning: Realigning the Sector for the Twenty-first Century, (London: Bedford Way Papers, Institute of Education, 1999), 13-15.

${ }^{39}$ D. Butler and J. Freeman, British Political Facts 1900-1967 (London: Macmillan, 1968), 197.
} 
Thus before the First World War, the transformation towards a modern educational system was far from being complete. The downturn period, 1920-1940, saw a conflict between the aspirations of educationists, as shown in the Hadow reports of 1926, 1931 and 1933, and proposals to raise the school-leaving age to 15 on the one hand, and the cutbacks in educational expenditure represented by the Geddes axe of 1922 and the May Report of 1931. Nevertheless, in spite of deflationary policies, the inter-war years saw a doubling of public educational expenditure as measured by constant prices. This included a doubling of public expenditure per elementary school pupil. Between 1923 and 1933 free places in secondary education rose from $38 \%$ to $50 \%$ of the whole, ${ }^{40}$ while the overall share of public expenditure devoted to secondary schooling rose from $6 \%$ to $9 \% .{ }^{41}$ During the inter-war years attendance in technical education doubled, while the percentage of public educational expenditure devoted to higher education rose from $0.5 \%$ to $2 \%$. Although Vaizey emphasised the effect of rising prices upon increases in educational expenditure during this period, ${ }^{42}$ these increases were essentially the result of the expansion and further transformation of the educational system. Much of this expansion was promoted by LEAs and represented a shift from taxes to rates. Indeed, central government grants accounted for only $38 \%$ of public expenditure on education in 1932 as opposed to $50 \%$ in 1922 .

The inter-war years saw the consolidation of the elementary school system and significant increases in public expenditure at secondary and higher education levels. The stage was set for the substantial transformation of these sectors in the post-1945 era.

\section{Post 1945 - education and the economy in concert}

Perceived changes in the relationship between public educational expenditure and economic growth which occurred after 1945 have been interpreted in different ways. For example, new growth theorists have argued that the endogenous accumulation of knowledge is the new driving force of economic growth. ${ }^{43}$ This is in line with systemic

\footnotetext{
${ }^{40}$ A. Morton, Education and the State from 1833 (Richmond: Public Record Office, 1997), 50.

${ }^{41}$ Carpentier, Système éducatif et performances économiques au Royaume-Uni.

${ }^{42}$ J. Vaizey, The Costs of Education.

${ }^{43}$ R. E. Lucas, 'Making a Miracle', Econometrica. 61 (1993), 251-272.
} 
regulation theory whose explanation of the reversal has also been linked with a separation of the education system from the productive system. ${ }^{44}$ While aspects of human development consequent upon education are increasingly linked with the development of employability, the recipients of education emancipate themselves from the role of correcting downturns in the economy. This is illustrated by the gradual rise of life long learning, which reflects a less strict separation between time for learning and time for production. ${ }^{45}$

\section{5-1973 The constitution of the comprehensive system and economic growth}

On one hand, the period 1945-1973 was characterised by a slower growth of the UK economy than those of competitors - sometimes explained in terms of a gradual catching up. For example, G. Abraham Frois has commented on the phenomenon of slow British growth from 1945 to 1973 and outlined its repercussions on the following downward phase. ${ }^{46}$ On the other hand, during this period economic performance undoubtedly improved - as shown by a doubling of GDP, an increase in the investment rate from 10 to $20 \%$ and an unemployment rate that did not exceed $2 \%$.

One explanation for the reversal of the link between education and economy is that while previous eras of economic growth were built upon a quantitative rise in the labour force, the post 1945 upswing rested fundamentally on its qualitative improvement. In consequence educational provision became more expensive. The period 1945-1973 saw a seven-fold rise in public expenditure on education, an increase in its percentage of GDP from $2.33 \%$ to $6.15 \%$ and of public expenditure from $7 \%$ to $13 \%$. Expenditure per pupil rose threefold between 1947 and 1973.

Peter Gosden has argued that the ideal of secondary education for all, one of the main aspirations of the inter-war period, secured widespread support during the Second World

\footnotetext{
${ }^{44}$ S. Michel, Education et croissance économique en longue période (Paris: L'harmattan, 1999).

${ }^{45} \mathrm{D}$. Vallade, Transformation historique du temps hors travail: une caractérisation économique des activités de formation loisir, Thèse de Doctorat en Sciences Economiques, Université Montpellier I, forthcoming.

${ }^{46}$ G. Abraham Frois, Préface in J. Marzellier L'économie de la Grande-Bretagne contemporaine (Paris: PUF, 1979), 12.
} 
War. ${ }^{47}$ The conflict was not only a period of rupture but also a crucial moment for launching socio-economic transformation in general and for education in particular. Many of the educational aims of the 1930s were realised through the Education Act of 1944. Free secondary schooling for all saw public expenditure on secondary education rise as a percentage of the whole from $10 \%$ in 1945 to $20 \%$ by 1961 . Nevertheless, many of the former hierarchies remained, as grammar schools, technical schools and modern schools continued to cater for $25 \%, 5 \%$ and $70 \%$ respectively of the population. ${ }^{48}$ Secondary education was no longer a separate system of schooling, but it remained strongly compartmentalised. Eric Hobsbawm was very critical of the 1944 Act, which in his view did little to reduce the very uneven character of secondary education. ${ }^{49}$ Not until the 1960s did the development of comprehensive secondary schools see a rise in the sector's share of public education expenditure to $30 \%$, thus exceeding that percentage devoted to primary schools.

Overall, expenditure for transport, sports and recreational activities and medical activities recorded a moderate growth, while that for meals quintupled. Meals were charged at the real cost supported by the school and were only free for the poorest children. ${ }^{50}$ Enrolment in special schools rose from 60000 to 160 000, generating a 20-fold increase in expenditure which now amounted to $4 \%$ of all public educational expenditure.

Other statistics for this period show a rise between 1947 and 1973 in educational participation rates of the 5-to-24 years old age group from $40 \%$ to $70 \%$ and an increase in the share of public educational expenditure spent on teacher training from $0.3 \%$ to $5 \%$. Furthermore, wages now constituted $70 \%$ of educational expenditure against $50 \%$ before the war.

\footnotetext{
${ }^{47}$ P. H. J. H. Gosden, Education in the Second World War, A Study in Policy and Administration (London: Methuen \& Co Ltd, 1976), 87.

${ }^{48}$ V. Lelaidier, L'éducation au Royaume-Uni (Paris: Ellipses, 1998), 62.

${ }^{49}$ E. J. Hobsbawm, Histoire économique et sociale de la Grande-Bretagne, Tome 2. De la Révolution Industrielle à nos jours (Paris: Edition du Seuil, 1977), 268.

${ }^{50}$ D. Garner, 'Education and the Welfare State: The School Meals and Milk Service, 1944-1980', The
} Journal of Educational Administration and History, XVII (1985), 65. 
In $197320 \%$ of pupils entered further education and, in sharp contrast to the pre-war period, by $197050 \%$ of students were engaged in full-time study. In 1966 some 30 polytechnics were created to compensate for the insufficient growth of universities. Only $2 \%$ of pupils reached university in 1951 compared to $8 \%$ in 1973. As higher education's share of public educational expenditure rose from $2 \%$ to $11 \%$, university finance and policies completely changed, as recommended by the 1946 Barlow Report and the 1963 Robbins Report. Over the period the amount of public finance received by universities as a percentage of their total income rose from $50 \%$ to $80 \%$. In contrast the percentages received from fees and donations fell from $23 \%$ to $4 \%$ and from $13 \%$ to $1 \%$ respectively. Full-time students constituted 70\% of the total in $1920,75 \%$ in 1945 and $90 \%$ in 1973. Postgraduate students amounted to $4 \%$ in 1946 and 20\% in 1973. In 1972 further rises in educational expenditure seemed inevitable as the result of the raising of the schoolleaving age, but in the following year economic downturn consequent upon the oil crisis produced a dramatic change.

\section{3-? : Economic crisis}

The 1973 oil crisis revealed the structural weaknesses in the UK economy, which was particularly hit by the recession. In 1969 a study presented to the Conference of Municipal Treasurers and Accountants had estimated that public expenditure on education would count for $8 \%$ of GDP in $1980 .{ }^{51}$ By this date, however, the percentage of public expenditure spent on education had fallen to 5\%. The post 1973 era demonstrated a conflict between the need to continue the educational development begun after the Second World War and the economic capacity or political will to provide ever-increasing public resources for education. The 1988 Education Reform Act was an example of the Conservative government's determination to apply market principles to education. ${ }^{52}$ Public expenditure on education grew more slowly in absolute terms from 1973, and showed significant reversals in policy in some sectors. For example, in higher education grants were replaced by loans and fees introduced. Between 1973 and 1999 the

${ }^{51}$ K. Ollerenshaw, 1970, Some Extrapolations by One of the Best Educational Statisticians in the Business, The Times, 14 April.

52 C. Knight, The Making of Tory Education Policy in Post-War Britain 1950-1986 (London: The Flamer Press, 1990), 135. 
percentage of university income received from central government declined from $80 \%$ to $50 \%$, while the proportion received from fees rose from $4 \%$ in 1975 to $22 \%$ in 1999 . Although overall enrolments increased, expenditure per student declined substantially in the 1970s and 1990s, the share of full-time courses declined from $80 \%$ to $60 \%$ and there was an increase in the student-teacher ratio.

\section{Conclusion}

Four points may be made in conclusion.

The first is that viewed from the perspective of this article the most important dates in British education history in the nineteenth century may be confirmed as those of 1833 and 1870 . On the other hand while the date of 1945 , identified here as a turning point in terms of a movement from countercyclical to procyclical explanations of the relationship between education and economic growth may be closely associated with the Education Act of 1944, the key twentieth-century date may be taken as $1973 .{ }^{53}$ This year symbolised the end of the apparently inexorable rise in public expenditure on education, and signalled a reversal in the relationship between public and private in education.

The second conclusion is that viewed in the longer term the relationship between public expenditure on education and economic growth in the UK does seem to have mirrored that already observed in France and Germany. Before 1945, major developments in public educational expenditure appear to have occurred during periods of economic downturn. These developments may be connected with attempts to improve the quality of the workforce. Central government initiatives were complemented by local efforts. Successive structural transformations led to the development of primary and secondary levels of schooling. After 1945 much public effort was devoted to the introduction of a comprehensive system of secondary schooling and an increase in higher education provision, elements in an emerging information revolution. ${ }^{54}$

The events of 1973 brought a halt to this expansion and a much more closely targeted use of educational resources. New initiatives focused upon closer links between education,

\footnotetext{
${ }^{53}$ One apposite educational event was the Ruskin Speech of 1976.

${ }^{54}$ J. Lojkine, La révolution informationnelle, (Paris: PUF, 1992); C. Freeman and F. Louçã, 2001.
} 
training and employment and found institutional expression in the creation of the DfEE and DfES. ${ }^{55}$

These similarities are of particular interest given the differences between the trajectories of economic growth and decline in the UK, France and Germany in the nineteenth century. The UK is generally acknowledged to have been at the forefront of the first industrial revolution but to have lagged behind in the second. The debate about the extent and nature of British economic decline in the last 30 years of the nineteenth century is too substantial to be summarised here. ${ }^{56}$ Nevertheless, some comments may be made on the respective roles of education and the economy. For example, E. G. West's suggestion that quantitative or qualitative shortages in the educational system occurred only with the intrusion of the state, which undermined educational development in a free market and lowered economic performance, seems to be wide of the mark. ${ }^{57}$ The results presented in this article indicate that increased public involvement in education was the consequence of economic crisis rather than its cause.

Some authors have argued that the UK's relative economic decline stemmed from the failure of its entrepreneurs to cope with technological change. ${ }^{58}$ Others have emphasised the low levels of technological competence in the British workforce. ${ }^{59}$ The hypothesis ${ }^{55}$ Aldrich, Crook and Watson, Education and Employment.

${ }^{56}$ See, for example, D. N. McCloskey, 'Did Victorian Britain Fail?', The Economic History Review. XXIII (1970), 446-459. D. H. Aldcroft, 'McCloskey on Victorian Growth: A Comment', The Economic History Review. XXVII (1974), 271-274; N. F. R. Crafts, British Economic Growth 1760-1913: A Challenge for New Growth Theory (Warwick: Department of Economics of University of Warwick, 1993).

${ }^{57}$ E. G. West, 'Educational Slowdown and Public Intervention in Nineteenth Century England: a Study on the Economics of Bureaucracy', Explorations in Economic History. 12 (1975), 61-87.

${ }^{58}$ D. S. Landes, The Unbound Prometheus, Technological Change and Industrial Development in Western Europe from 1750 to the Present (Cambridge University Press, 1979). D. H. Aldcroft, 'The Entrepreneur and the British Economy, 1870-1914', The Economic History Review. XVII (1964).

${ }^{59}$ C. Barnett, The Collapse of British Power, (Alan Sutton, 1972), 97; W. P. Kennedy, ' Economic Growth and Structural Change in the United Kingdom 1870-1914', The Journal of Economic History. XLII (1982), 105-114; M. Dintenfass, The Decline of Industrial Britain, 1870-1980, (London: Routledge, 1992); B. Supple, 'Fear of Failing : Economic History and the Decline of Britain', The Economic History Review. XLVII (1994), 441-458; M.J. Wiener, English Culture and the Decline of the Industrial Spirit 1850-1980 (Cambridge University Press, 1981). 
advanced in this article is that while public investment in education in the UK rapidly increased during the period of the Great Depression, delays in establishing a public system of education in the period prior to 1870 meant that much of this investment should be seen in terms of remedying deficiencies. Thus although, as Michael Sanderson has argued, the years 1870-1914 were a period of educational development, ${ }^{60}$ such development would still lag behind those of some competitor countries. Not until the post-1945 era was a closer link forged between education and the economy with recognition of the importance of skills, information and innovation to modern economic growth.

The final point is that this article represents a first step. A better understanding of the link between education and economic growth will require further research in two areas. The first is the development of new indicators to measure the quality of education as well as its quantity. ${ }^{61}$ The second is the application of such indicators to provide more sophisticated comparisons between the education and economic performance of the UK and its major competitors.

\footnotetext{
${ }^{60}$ M. Sanderson, 'Education and Economic Decline, 1870-1914. An Innocent Suspect?', 155-174, in J. P. Dormois and M. Dintenfass (Eds) The British Industrial Decline (London: Routledge, 1998).

${ }^{61} \mathrm{~K}$. Caner La dynamique qualitative du produit de l'éducation, Thèse de Doctorat en Sciences Economiques, Université Montpellier I, 2000.
} 